\title{
人工磯における付着動物の垂直分布 に関する現地調査 \\ FIELD OBSERVATIONS ON VERTICAL DISTRIBUTION OF MARINE ORGANISMS IN MAN-MADE ROCKY COAST
}

\author{
端谷研治 $1 \cdot$ 柴橋朋希 $2 \cdot$ 谷口正典 $2 \cdot$ 吉安勇介 2 \\ 井上雅夫 $3 \cdot$ 島田広昭 4
}

\section{Kenji HASHITANI, Tomoki SHIBAHASHI, Masanori TANIGUCHI, Yusuke YOSHIYASU Masao INOUE and Hiroaki SHIMADA}

\author{
1正会員 工修 日本建設コンサルタント（株）（†105-0004 東京都港区新橋 6-17-19） \\ 2 学生員 関西大学大学院 工学研究科（T564-8680 大阪府吹田市山手町 3-3-35) \\ ${ }^{3}$ 正会員 工博 関西大学教授 工学部土木工学科（广564-8680 大阪府吹田市山手町 3-3-35） \\ 4 正会員 工博 関西大学講師 工学部土木工学科 ( $5564-8680$ 大阪府吹田市山手町 3-3-35)
}

\begin{abstract}
The purpose of this study is to establish the construction technique of man-made rocky coast with various marine organisms. From this viewpoint, the field observations on vertical distribution of marine organisms were carried out in three man-made rocky coasts at Osaka Bay and Tohban coast.

As a result, the vertical distribution of marine organisms varies with the rate of seawater flow due to wave and current. And, between critical inhabiting height of marine organism and the rate of seawater flow, there is the linear relation approximately. It is suitable for the beach play in the place which faced the open sea side in the man-made rocky coast.
\end{abstract}

Key Words: Man-made rocky coast, marine organisms, diversity index, prosperity index

\section{1. 緒 蛋}

近年, 我が国においては，海岸環境整備事業などによ って人工磯が造成されるようになってきた. しかし，そ の施工例は人工の砂浜に比べると非常に少なく，その造 成技術に関しての指針も，いまだ確立されていないのが 現状であろう.

著者らは,これまで大阪湾沿岸や東播海岸にある人工 磯の付着動物に関する現地調查を行い，その平面形状や 造成素材に関しては，ある程度の知見を得ることができ た ${ }^{1,2)}$.

この論文では, 人工磯における付着動物の垂直分布を 調査し, これによって, 付着動物の多様性や繁栄性を向 上させるためには, 人工磯の高さなどを含めた断面形状 をどのようにすれば効果的であるかを明らかにしようと した.

\section{2. 調查方法}

人工磯における付着動物の垂直分布を明らかにするた め, 大阪湾沿岸や東播海岸にある 3 力所の人工磯におい て現地調査を行った. 図-1(a), (b)および(c)には, 調査対 象地とした淡輪・箱作, 魚住および大蔵海岸の人工磯に 設置した測点の位置を示した. まず，それぞれの人工磯 に高さの等しい測点を設け, それらのなかの 3 測点（淡 輪・箱作海岸の人工磯では測点 $\mathrm{Z} 6, \mathrm{Z} 7$ および $\mathrm{Z} 10$, 魚 住海岸のものは $\mathrm{P} 1, \mathrm{P} 3$ および $\mathrm{P} 5$, 大蔵海岸のものは測 点 $\mathrm{A6} \sim \mathrm{A} 8)$ において, 辺長が $50 \mathrm{~cm}$ 方形枠を人工磯の のり面に沿って置き, その枠内での付着動物の種数およ び個体数を目視により調査した. しかし,こうした調查 では, 海面からの高さに加え, 磯表面の凹凸などの影響 も大きいため, 淡輪・箱作海岸の人工磯において, 表面 に一様な粗度をつけた $25 \times 50 \mathrm{~cm}$ のコクリートブロッ 


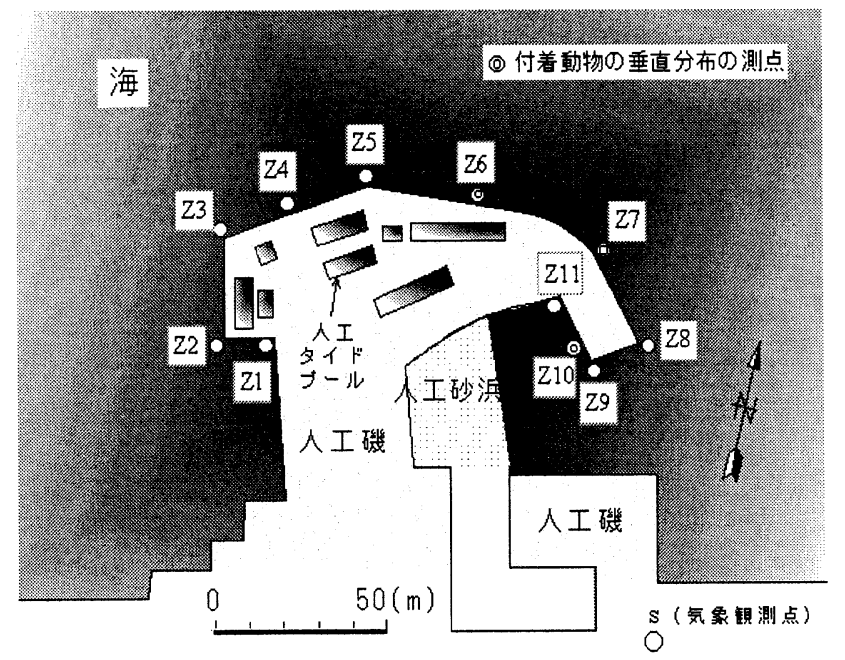

(a) 淡輪・箱作海岸

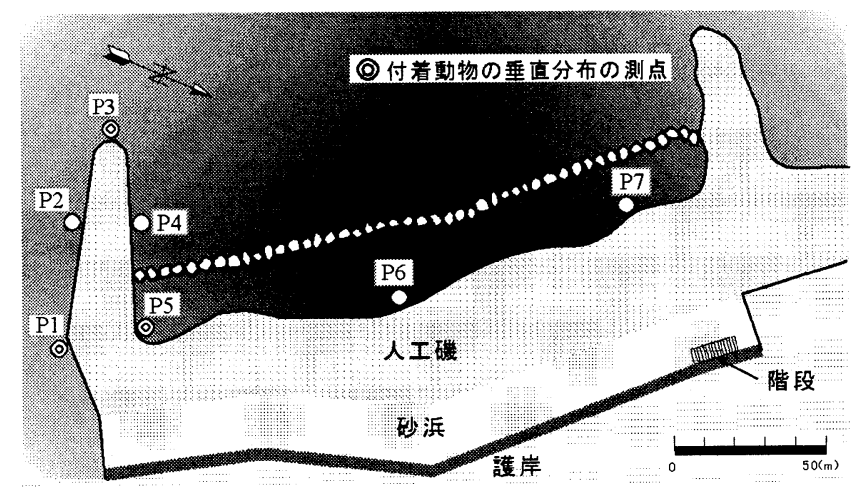

(b) 魚住海岸

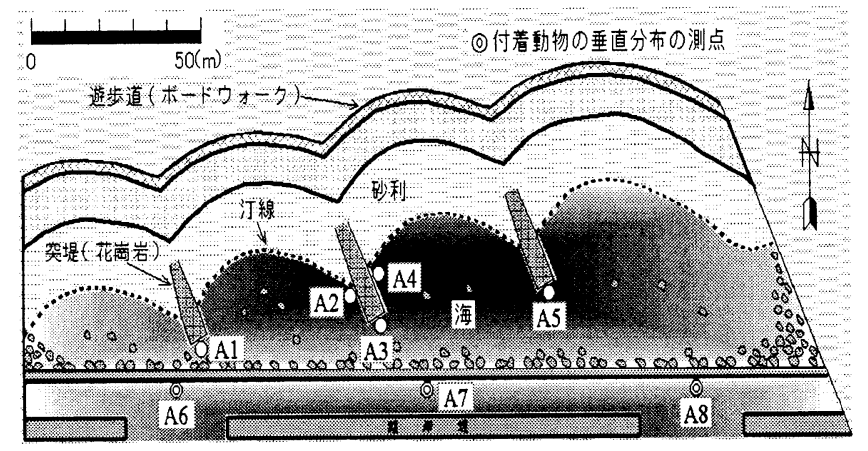

(c) 大蔵海岸

\section{図-1人工磯の地形と測点の位置}

ク供試体をのり面に沿って 8 個設置し, そこでの付着動 物の種数および個体数を測定することによって, 高さの 違いのみによる付着動物の垂直分布を検討した. また, この供試体のものとそれに接した人工磯のものとを比較 することによって, 岩石間の空隙などが付着動物の多様 性や繁栄性に及ぼす影響を明らかにした。

さらに，それぞれの人工磯における全測点の最も高い 位置に生息している付着動物種とその高さを測定し，そ こを付着動物の生息限界高さと定義した. また，淡輪・ 箱作の人工磯では, 付着動物の個体数が最も多いところ の高さも測定し，それを生息繁栄高さと定義した.
なお，これらの調査は，淡輪・箱作海岸では，1997 年 8 月から 2000 年 12 月までの間に 12 回, 魚住海岸では 1998 年 9 月から 1998 年 12 月までの間に 3 回, 大蔵海 岸では 1999 年 8 月から 1999 年 12 月までの間に 3 回, それぞれ実施した. また，いずれの調査日においても， 気象 (天候, 気温, 湿度, 風向, 風速), 水質 (水温, 塩 分濃度, $\mathrm{pH}, \mathrm{DO}, \mathrm{COD})$ の測定とともに, 石高ボール 法 3)によって波当たりの測定も行った.

\section{3. 調查結果および考察}

\section{(1) 人工磯における付着動物の生物指標の垂直分布}

図-2(a)，(b)では，淡輪・箱作および魚住海岸における 測点を突堤の沖側と岸側, 図-2(c)では大蔵海岸における 測点を離岸堤開口部と背後部にそれぞれ分類し，そこで の付着動物に関する生物指標 4), 5) と海面からの高さとの 関係を季節ごとに示した.

図-2(a)に示した淡輪・箱作海岸のものをみると, 多様 度指数については, 全般的に, 突堤の岸側よりも, 沖側 での值が大きい. また, 季節的にみると, 多様度指数は, 沖側では海面からの高さに関倸なく, 冬季に極小值を示 し，岸側でも，ほぼ同様の傾向がみられる．さらに，突 堤の沖側では O.P.+0.85mでの多様度指数が年間を通じ て大きく, その岸側では, 海面からの高さが低いところ ほど多様度指数は大きい. 繁栄指数については, 多様度 指数と同様に, 全般的に岸側よりも沖側での值が大きい. また，沖側では，高さに関係なく冬季に極小值を示すの に対し，岸側では，冬季にその值が大きくなる傾向がみ られる.

図-2(b)に示した魚住海岸のものをみると, 多様度指数 は，ほとんどの季節で突堤の岸側で大きく，沖側では小 さい. また，岸側での夏季や秋季の值は，海面からの高 さが低いところほど, 若干ではあるが，大きくなる傾的 がみられる. しかし，沖側ではそのような傾向は必ずし もみられない，繁栄指数は，多様度指数之同様に，全般 的に岸側での值が大きい. 季節的にみると, 岸側では海 面からの高さに関係なく, 秋季にその值が大きくなるの に対し, 沖側では, O.P.+1.25mのところでしか, そのよ うな傾向はみられない.

図-2(c)に示した大蔵海岸では, 離岸堤開口部よりも, その背後部での多様度指数が全般的に大きい. また, 離 岸堤の開口部之背後部のいずれについても, 海面からの 高さが低いところほど, 多様度指数は大きい. 繁栄指数 は, 波当たりの弱い離岸堤背後部よりも, その開口部で 大きい. また, その背後部では, 夏季のものに限定され るが, 海面からの高さが低いところほど, 繁栄指数は大 きい.

このように人工磯における付着動物の垂直分布を検討 したが，磯ごとで測点の高さが異なるため，これらを直 

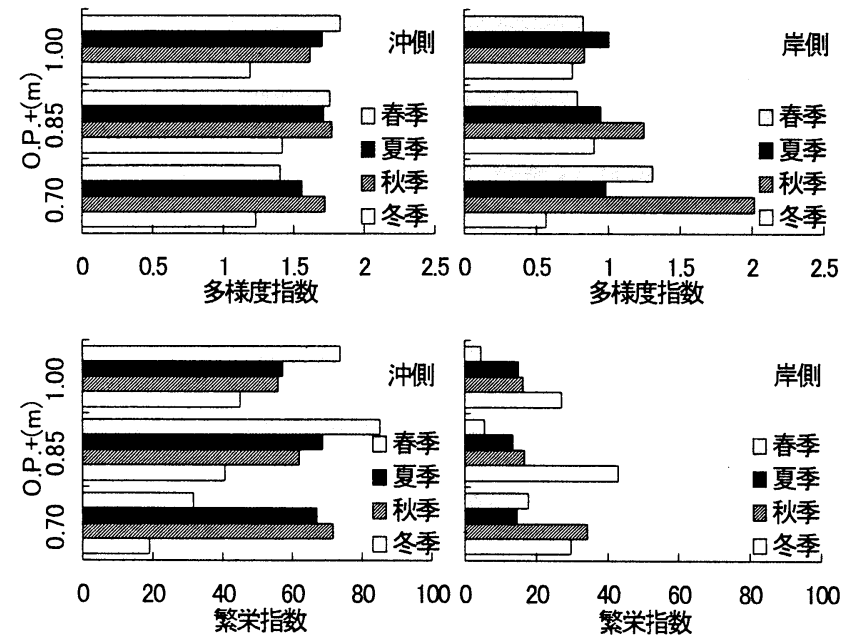

(a) 淡輪 $\cdot$ 箱作海岸
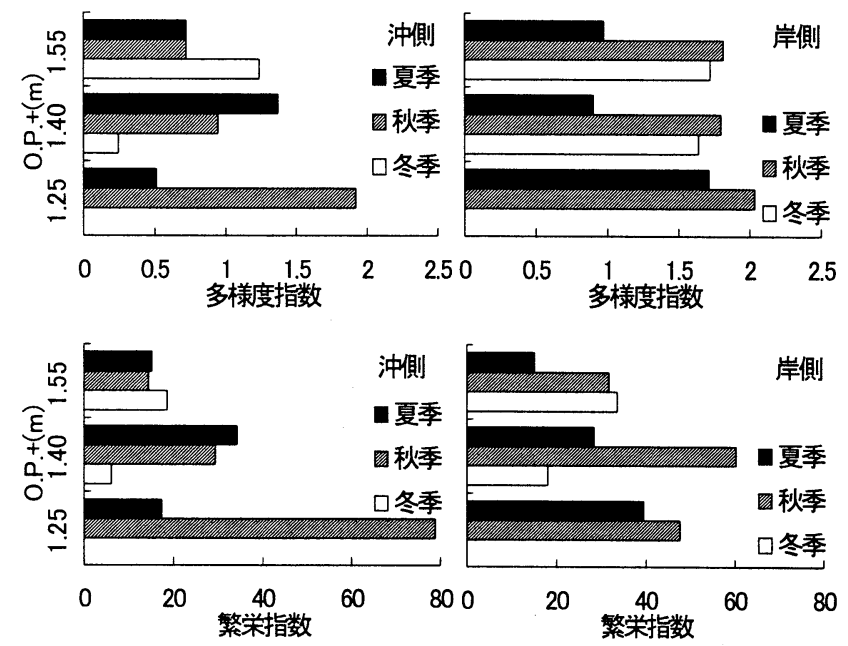

(b) 魚住海岸
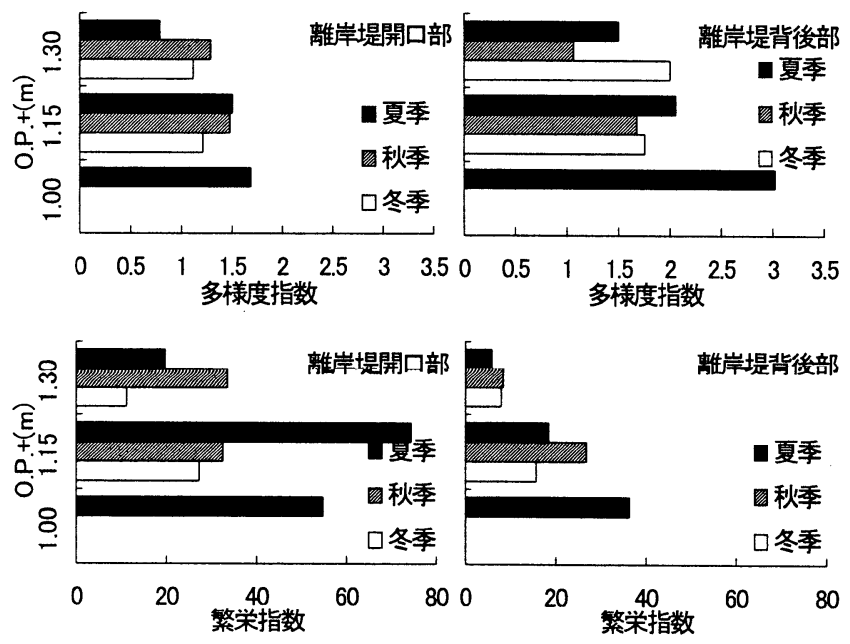

(c) 大蔵海岸

図-2人工磯における生物指標の垂直分布

接比較することは困難であった. しかし, 淡輪・箱作, 魚住海岸における突堤の岸側や大蔵海岸における離岸堤 背後部のように波当たりの弱いところでは, 海面からの 高さが低いところほど, 付着動物の多様性は高くなるこ
となど，いずれの人工磯においても共通の傾向が示され た.これは，波当たりの弱いところでは，海面からの高 さの低いところでしか，湿潤状態が保たれにくいためで ある.

(2) 高さごとの付着動物の生息割合

図-3(a)，(b)および(c)には，前述した垂直分布における 付着動物の生息割合を示した. なお，分類に関する詳細 は表-1に示すとおりである.

まず, 図-3(a)に示した淡輪・箱作海岸のものをみると, 突堤の沖側では, 海面からの高さに関係なく, ツ夕ノハ ガイ科に属するヨメガガサガイやマツバガイなどの生息 割合が高い。一方, 岸側では, ニシキウズガイ科に属す

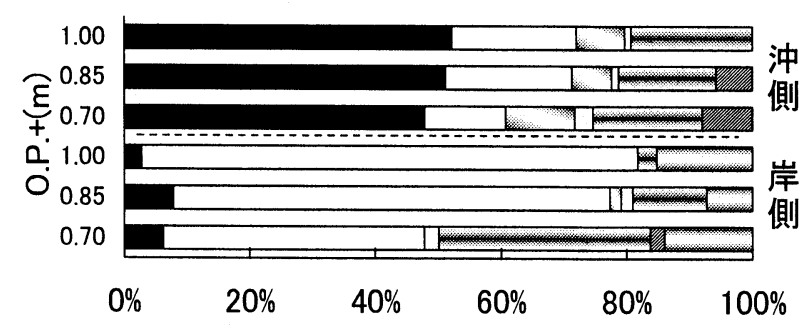

(a) 淡輪・箱作海岸

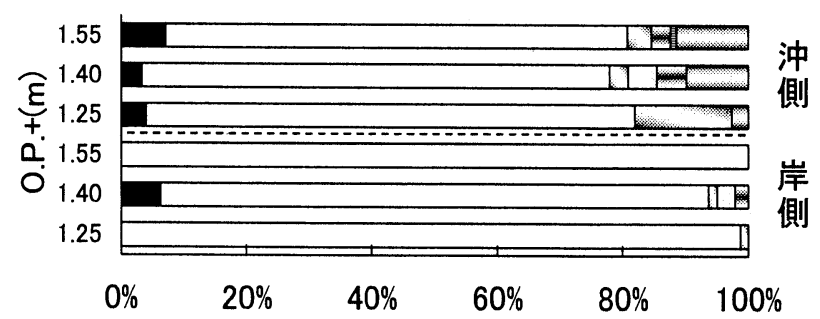

(b) 魚住海岸

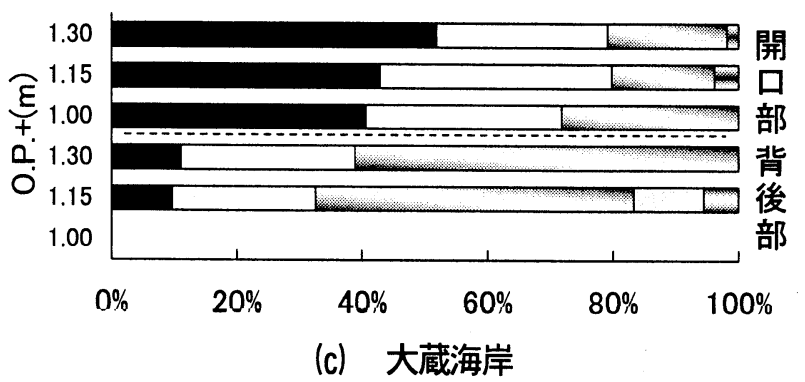

図-3 高さごとに示した付着動物の生息割合

表-1 付着動物の主な分類

\begin{tabular}{|c|c|}
\hline ロ ツタノハガイ科 & $\begin{array}{c}\text { ヨメガガサガイ } \\
\text { マツバガイ }\end{array}$ \\
\hline$\square$ ニシキウズガイ科 & $\begin{array}{c}\text { イシダタミガイ } \\
\text { コシダカガンガラ }\end{array}$ \\
\hline アクキガイ科 & イボニシ \\
\hline ヒザラガイ科 & ヒザラガイ \\
\hline ユキノガサガイ科 & $\begin{array}{c}\text { アオガイ } \\
\text { ウノアシ } \\
\text { コガモガイ }\end{array}$ \\
\hline உコウダカカラマツガイ科 & カラマツガイ \\
\hline タマキビガイ科 & タマキビガイ \\
\hline
\end{tabular}


るコシダカガンガラやイシダタミガイなどの生息割合が 高く，それは海面からの高さが高いところほど顕著であ る. 逆に海面からの高さの低いところでは, 大きさが比 較的小さな笠貝の一種でユキノカサガイ科に属するアオ ガイ類の生息割合が高い.

図-3(b)に示した魚住海岸では，そこに設置した測点の 高さが高いため, 突堤の沖側と岸側のいずれについても, 海面からの高さに関係なく，ニシキウズガイ科に属する ものの生息割合が高い.

図-3(c)に示した大蔵海岸では, 離岸堤開口部において, ツタノハガイ科に属するものの生息割合が，若干ではあ るが高い. また, 離岸堤背後部では, 海面からの高さが 高いところほど, 巻貝の一種でニシキウズガイ科やアク キガイ科に属するものの生息割合が高い.

以上のように, 淡輪・箱作や大蔵海岸の人工磯で波当 たりの強いところでは, いずれの高さにおいても, ツタ ノ八ガイ科に属するものの生息割合が高い.一方，波当 たりの弱いところでは，海面からの高さが高いところほ ぞ, ニシキウズガイ科に属するものの生息割合が高くな る.一般にツタノハガイ科に属するマツバガイなどは笠 貝の一種であり, 波当たりに対し, 強い耐性をもってい る. そのため, 海面からある程度の高さのところまで波 当たりのある突堤の沖側では，これらの種が多く生息す るものと思われる. しかし, 突堤の岸側のように波当た りの弱い場所では，波当たりに対して耐性の弱い巻貝の 一種でニシキウズガイ科に属するものが多い. また，そ の生息場所は湿潤状態が保たれやすい海面付近に限定さ れる.

\section{（3）供試体における付着動物の垂直分布}

図-4 には，供試体における付着動物の多様度指数およ び繁栄指数の垂直分布を示した.

まず，多様伎指数と海面からひ高さとひ間に明睹な関 係はみられないが，いずれの季節においても， O.P. $+0.75 \mathrm{~m}$ 付近での值が最も大きい. また, O.P. $+0.50 \mathrm{~m}$ やO.P.+1.05m 付近のものは, ほとんどの季節において, その值が小さい. 繁栄指数は, 季節的にばらつきがみら れるが, 海面からの高さが低いところほど, その值は大 きい. 特に, O.P. $+0.50 \mathrm{~m}$ 付近では, 季節的な変動も小さ い.

以上のように, 供試体における付着動物の繁栄指数は, 海面からの高さが低いところほど大きくなるが, 多様度 指数は O.P. $+0.75 \mathrm{~m}$ 付近で最大值を示すことが明らにな った. また，海面からの高さが低いところほど繁栄指数 は大きいのに対し，多様度指数は小さいことから，千潮 汀線付近では, 優占種が発生しやすいものと考えられる.

(4) 人工磯と供試体における付着動物の垂直分布の比較

図-5 には, 淡輪・箱作海岸の測点 Z6 とその付近に設置
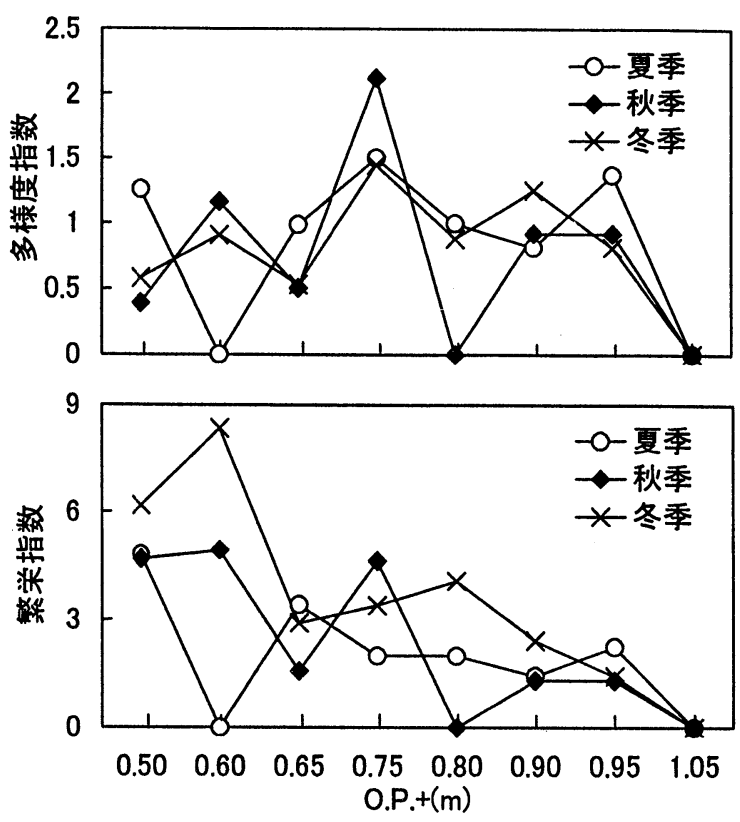

図-4＼cjkstart供試体における生物指標の垂直分布

した供試体における付着動物の多様度指数と繁栄指数の 垂直分布を示した.

多様度指数は, 測点 Z6 では O.P.+0.75m 付近が最も大 きく, 供試体のものも，ほぼ同様の傾向がみられるが多 様度指数は小さい. 写真 -1 には, O.P.+0.75m 付近の人工 磯の測点 Z6 と供試体の表面形状を示した. これからもわ かるように, 測点 Z6 には空腙が存在し, これが多様性を 高めているものと思われる.

繁栄指数についてみると, 海面からの高さに関係なく, 測点 Z6 のものが供試体のものよりも大きい.このことか らも空隙が付着動物の生息に適した環境を創出している ことが確認できる.
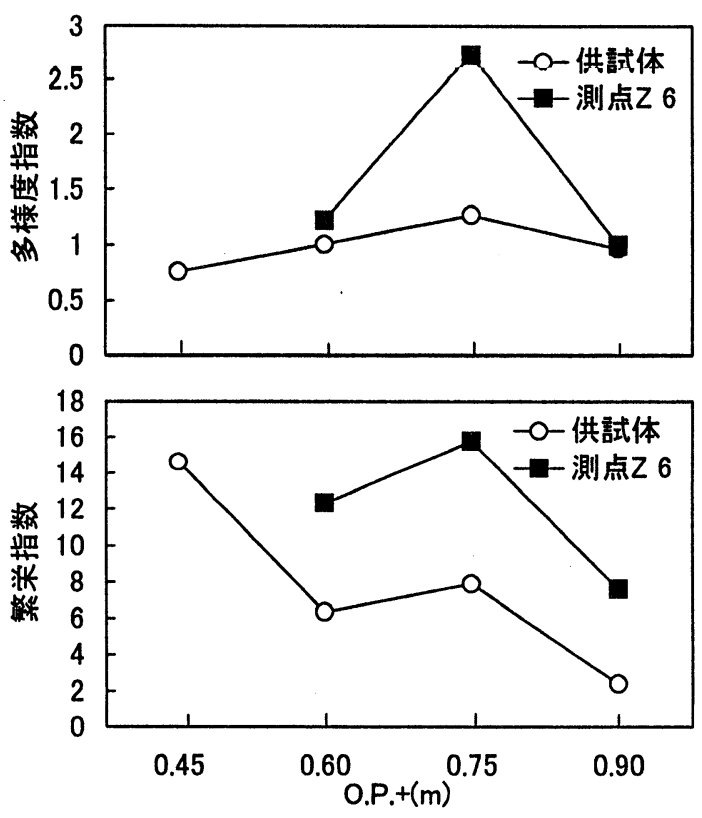

図-5 人工磯と供試体における生物指標の垂直分布 


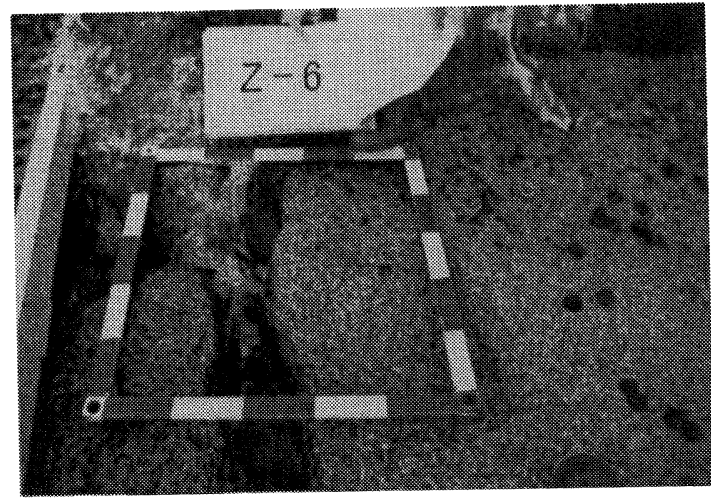

測点 Z 6

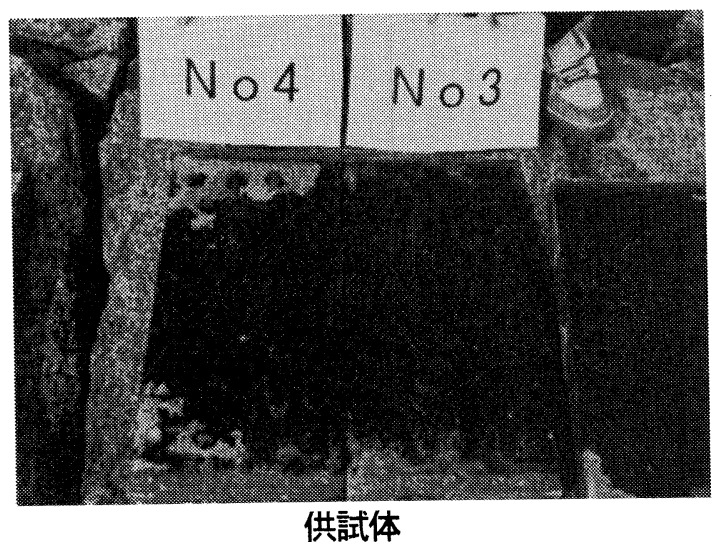

写真-1 測点 Z 6 と供試体の表面状況

\section{(5) 人工磯における付着動物の生息限界高さ}

図-6(a)，(b)および(c)には，それぞれ淡輪・箱作，魚住 および大蔵海岸における付着動物の生息限界高さを示し た.

図-6(a)に示した淡輪・箱作海岸のものでは，いずれの 季節においても, Z3〜Z8 のような沖側に面した測点での 生息限界高さは, Z1，Z2，Z9～Z11 のような岸側に面し た測点のものに比べて高い. また，季節的には，いずれ の測点においても, 夏季での值が最も低い. 特に測点 Z5 やZ6では, 秋季や冬季にその值が高い.

図-6(b)に示した魚住海岸のものでは，いずれの季節に おいても, $\mathrm{P} 2$ P4 のような沖側の測点における生息限界 高さが高く, P1, P5〜P7 のような岸側の測点では低い. また，季節的にみると，生息限界高さは，ほとんどの測 点において冬季のものが高いが，沖側では秋季に，岸側 では夏季に低くなる.

図-6(c)に示した大蔵海岸では, 他の人工磯と同様に, 沖側の測点 $\mathrm{A} 6$ や $\mathrm{A} 8$ での生息限界高さが高く, 岸側の測 点 $\mathrm{A} 1$ A 5 では低い. また，季節的には，ほとんどの測 点において, 夏季の生息限界高さが最も低い.

以上のように, 付着動物の生息限界高さは, いずれの 人工磯においても, 沖側で高く, 岸側で低くなることが 明らかになった. また, その值は, 夏季に比べて秋季や 冬季のものが高い.これらのことから, 付着動物の生息 限界高さには，そこでの波当たりの強弱が影響を及ぼし
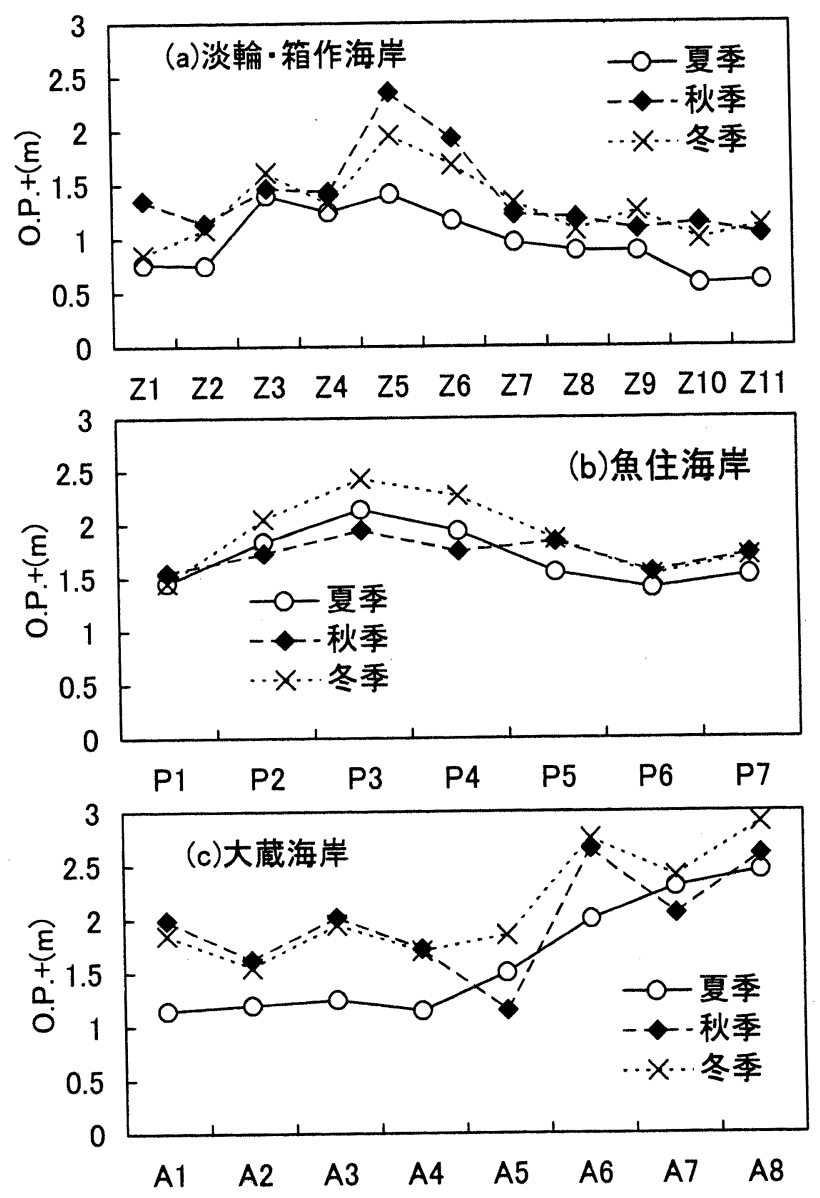

図-6人工磯における付着動物の生息限界高さ

ているものと考えられる.

そこで図·7には，それぞれの人工磯における海水流動 值と生息限界高さとの関係を示した.

これによると, いずれの人工磯においても, 多少のば らつきはみられるが, 海水流動值が大きくなるほど, 生 息限界高さが高くなる傾向がみられる. すなわち, 海水 流動値の大きいところでは, 波の打ち上げや飛沫によっ て, 海面からの高さが高いところまで湿潤状態が保たれ, そのような場所でも付着動物が生息可能な環境が創出さ れているためである.

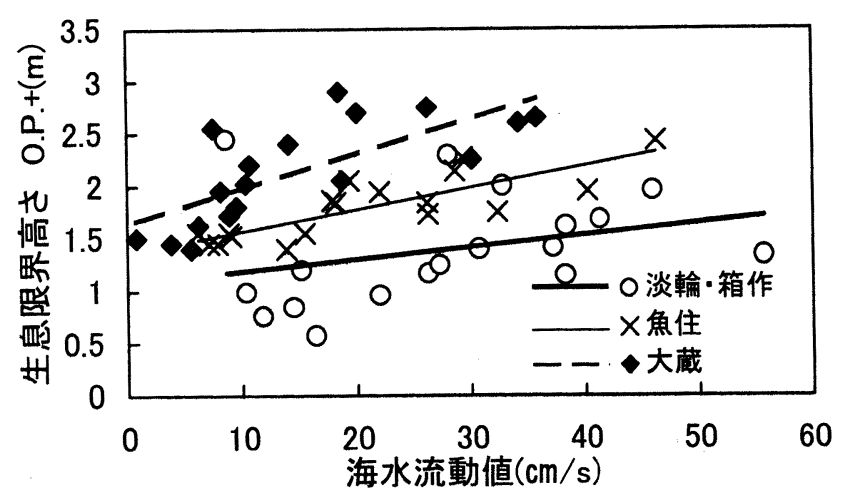

図-7各人工磯における海水流動値と生息限界高さ 


\section{(6) 磯遊び幅とその平面分布}

人工磯の利用者が磯観察を行える範囲を量的に表現す るために，付着動物の個体数が最も多いところの高さを 生息繁栄高さとし，それと生息限界高さとの間の領域を 図-8に示すように“磯遊び幅”と定義した.

図-9 には，淡輪・箱作海岸の各測点における磯遊び幅 と生息繁栄高さでの多様度指数を示した.
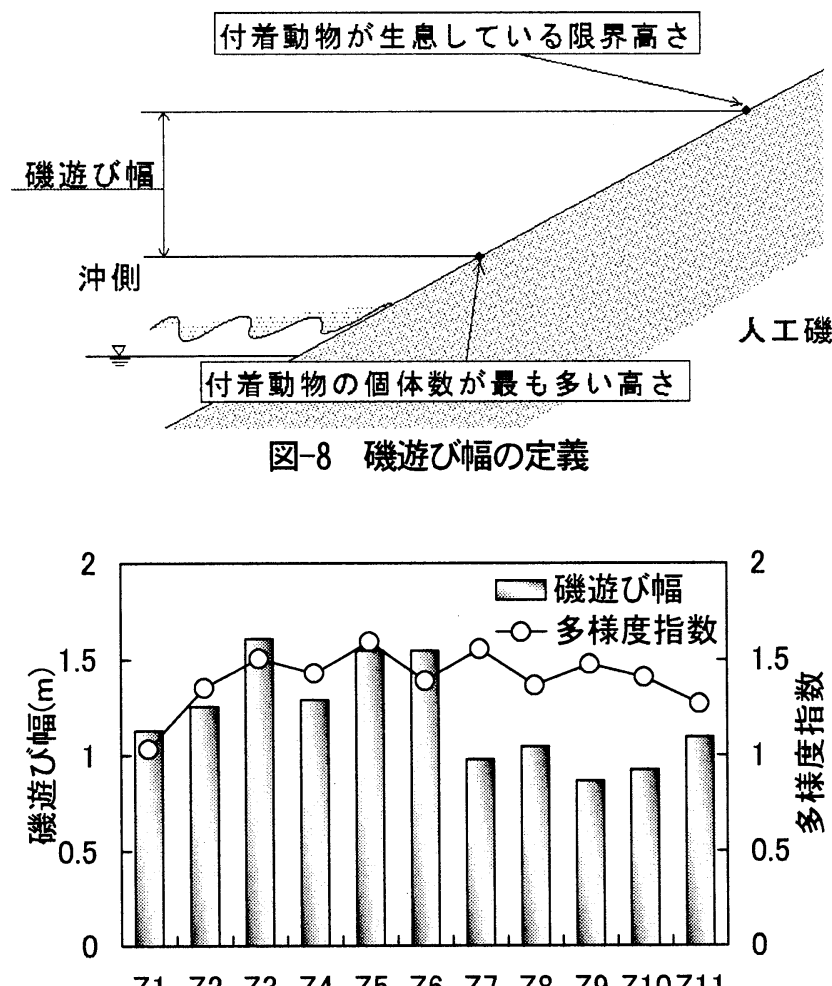

$\begin{array}{lllllllllll}\text { Z1 } & \text { Z2 } & \text { Z3 } & \text { Z4 } & \text { Z5 } & \text { Z6 } & \text { Z7 } & \text { Z8 } & \text { Z9 } & \text { Z10Z11 }\end{array}$

\section{図-9 淡輪・箱作海岸の各測点における磯遊び幅と多} 様度指数

これによると，磯遊び幅は，沖側に面した測点 Z3〜Z6 で広く，岸側に面した測点 Z1，Z2 およびZ9〜Z11 では 狭い. また, 生息繁栄高さでの多様度指数に関しても, 岸側よりも沖側に面した測点のものが若干大きい. 害際, 沖側での生息繁栄高さのところには，ヨメガガサガイ， マツバガイ, アオガイなどの笠貝に加え，イシダタミガ イやイボニシなどの巻貝, さらにはフジツボ類やヒザラ ガイなど, 多様な付着動物が生息している. 一方, 岸側 では, イシダタミガイやコシダカガンガラなどの巻貝の 優占傾向が顕著であった. すなわち, 人工磯の沖側は, 磯遊び幅が広いだけでなく, 多様な付着動物が生息して おり，磯観察の場として適しているものと考えられる.

\section{4. 結 語}

以上，人工磯における付着動物の垂直分布を調査して きたが，それらの結果をまとめると，次のようになる.
(1)人工磯における突堤の岸側や離岸堤背後部のように 波当たりの弱いところでは, 海面からの高さが低いほど 付着動物の多様性は高くなる. しかし, 波当たりの強い ところでは，そのような傾向はみられない。これは，波 当たりの強いところでは, 海面からの高さが高くても湿 潤状態が保たれるためである.

(2)淡輪・箱作および大蔵海岸の人工磯における波当た りの強いところでは，いずれの高さにおいても，ヨメガ ガサガイのようなツタノハガイ科, アオガイのようなב キノカサガイ科に属する笠貝の生息割合が高い。これに 対し，波当たりの弱いところでは，海面からの高さが高 くなるほど, イシダタミガイやコシダカガンガラのよう なニシキウズガイ科に属する巻貝の生息割合が高くなる.

(3)人工磯とコンクリートの供試体では，いずれも O.P.+0.75m 付近で多様度指数や繁栄指数などの生物指 標の値は大きい，また，岩石間の空隙などの存在によっ て，人工磯における付着動物の多様性や繁栄性は，コン クリートの供試体のものよりも高い.

(4)海水流動值が大きいところでは, 海面からの高さが 高いところまで湿潤状態が保たれるため, 付着動物の生 息限界高さは高くなる.

(5)生息限界高さと付着動物の個体数が最も多いところ の高さとの差を磯遊び幅と定義した．突堤の沖側では磯 遊び幅が岸側に比べて広いだけでなく，そこでは多数の 付着動物種が確認されるため, 子供たちの磯観察の場に 適している.

㖶辞 : 最後に, 本研究を行うにあたり, 多くのご協力を いただいた関係官庁の各位，ならびに調査や資料整理に 熱心に協力してくれた関西大学海岸工学研究室の学生諸 君に謝意を表する. なお，この研究には，関西大学学術 フロンティア・センターの研究費を使用した.ここに明 記して謝意を表する。

\section{参考文献}

1)井上雅夫・島田広昭・桜井秀忠・柄谷友香 : 生物との 共生をめざした人工磯の造成素材に関する現地調査, 海岸工学論文集, Vol.45(2), pp.1116 1120， 1998.

2)端谷研治・井上雅夫・島田広昭・柴橋朋希 : 人工磯に おける付着動物の生息分布に関する現地調査，海洋開 発論文集, Vol.16, pp.321〜326, 2000.

3)鍋島靖信・喜田和四郎 : 石高ボールによる海水流動值 の測定法，水産増殖，Vol.38-2，pp.127～133， 1990. 4)木元新作: 動物群集研究法 I 一多様性と種類組成一, pp.54 64, 共立出版, 1976.

5)木元新作・武田博清: 群集生態学入門, pp.123 129, 共立出版, 1989. 